\section{Gy 4 Cucumber Inbred and 'Raleigh' Hybrid Pickling Cucumber}

Richard L. Lower'

Department of Horticulture, University of Wisconsin, Madison, Wl 53706

Todd C. Wehner ${ }^{2}$ and Samuel F. Jenkins, Jr. ${ }^{3}$

North Carolina State University, Raleigh, NC 27695-7609

Additional index words. Cucumis sativus, vegetable breeding
Gy 4 is a multiple disease-resistant, gynoecious cucumber (Cucumis sativus L.) inbred. It has high combining ability for either once-over or multiple harvest yield producing high-yielding hybrids when crossed to monoecious inbred lines. In addition, it has a high level of resistance to anthracnose (Colletotrichum orbiculare) and angular rymans) under Wisconsin and North Carolina field conditions, including the recently identified virulent strain of Colletotrichum found in central Wisconsin (personal communication, M.J. Palmer).

Gy 4 has proved its value in hybrid combination with the monoecious inbred, NCSU M 21, and we have named the hybrid 'Raleigh'. 'Raleigh' pickling cucumber had $12 \%$ more yield ( $\$ /$ ha in six harvests) than ' $\mathrm{Ca}$ lypso', the major cultivar in North Carolina (Table 1). It also had 26\% more early yield (\$/ha in the first two harvests of a six-harvest trial) than 'Calypso'. Fruit quality (shape, color, and seed cell size), length : diameter (L: D) ratio, firmness, and bloater resistance were similar to 'Calypso'. 'Raleigh' was

Received for publication 5 Sept. 1989. We gratefully acknowledge the technical assistance of J.C. Mather and R.R. Horton, Jr. The cost of publishing this paper was defrayed in part by the payment of page charges. Under postal regulations, this paper therefore must be hereby marked advertisement solely to indicate this fact.

${ }^{1}$ Professor of Horticulture.

${ }^{2}$ Professor of Horticultural Science.

${ }^{3}$ Professor of Plant Pathology (deceased). leafspot (Pseudomonas syringae pv. lach- standard cultivars for yield (Table 2) and had processing quality equal to 'Calypso' (data not shown).

\section{Origin}

Gy 4 originated from the cross of the multiple disease-resistant gynoecious inbred Gy 14 with the high-yielding, high fruit quality monoecious inbred NCSU 19D4 (Fig. 1). Segregating populations were tested for disease resistance in the seedling stage, and for yield, earliness, quality, gynoecious expression, bloater resistance, and disease resistance in the field. Lines inbred to the $F_{8}$ (NCSU) and $\mathrm{F}_{13}(\mathrm{UW})$ were tested for disease resistance and gynoecious expression before being selected for final increase in isolated field plantings.
Table 1. Performance of 'Raleigh' hybrid (Gy $4 \times \mathrm{M} 21$ ) compared with a set of standard pickling cucumber cultivars for the southeastern United States. ${ }^{2}$

\begin{tabular}{lccccccc}
\hline \hline Cultivar & $\begin{array}{c}\text { Yield } \\
(\$ / \mathrm{ha})\end{array}$ & $\begin{array}{c}\text { Earliness } \\
(\$ / \mathrm{ha})\end{array}$ & $\begin{array}{c}\text { Quality } \\
1-9\end{array}$ & $\begin{array}{c}\text { Anthracnose } \\
0-9\end{array}$ & $\begin{array}{c}\text { Firmness } \\
(\mathrm{kg})\end{array}$ & $\begin{array}{c}\text { L : D } \\
\text { ratio }\end{array}$ & $\begin{array}{c}\text { Balloon } \\
(\%)\end{array}$ \\
\hline Raleigh & 4850 & 2060 & 6.0 & 3.5 & 8.6 & 3.1 & 2 \\
Explorer & 3710 & 1380 & 6.2 & 4.4 & 9.1 & 2.9 & 4 \\
Carolina & 3980 & 1590 & 6.3 & $4: 8$ & 9.1 & 3.0 & 5 \\
Calypso & 4310 & 1640 & 6.3 & 3.8 & 9.1 & 3.1 & 3 \\
Regal & 4960 & 1740 & 5.6 & 4.4 & 8.2 & 3.2 & 3 \\
LSD (5\%) & 519 & 393 & 1.0 & 0.9 & 0.5 & 0.1 & 2 \\
\hline
\end{tabular}

${ }^{2}$ Data are means over 3 years $(1983,1984,1985)$, two seasons (spring, summer), and three replications. Yield data are summed over six harvests. Dollar values based on North Carolina processor prices for grades one through four. Earliness is the value of the fruits from harvests one and two. For quality, 1 $=$ poor, $9=$ excellent; for anthracnose, $0=$ no disease, $9=$ plant dead. Firmness is the force required to punch a hole in 45 -mm-diameter fruits (10-fruit samples) with a Magness-Taylor tester having an 8$\mathrm{mm}$ tip. $\mathrm{L}: \mathrm{D}$ is the length : diameter ratio of $35-\mathrm{mm}$-diameter fruits (10-fruit samples). Balloon is the percentage of the fruit tissue damaged by balloon bloating in a brine tank purged with $100 \% \mathrm{CO}_{2}$ gas.

Table 2. Performance of 'Raleigh' hybrid (Gy $4 \times \mathrm{M} 21$ ) compared with a set of standard pickling cucumber cultivars in 1983 through 1986 in Wisconsin.

\begin{tabular}{|c|c|c|c|c|c|c|c|c|c|}
\hline \multirow[b]{2}{*}{ Cultivar } & \multicolumn{3}{|c|}{1983} & \multicolumn{3}{|c|}{1984} & \multicolumn{3}{|c|}{1986} \\
\hline & Fruits/plant & $\begin{array}{c}\text { Yield } \\
\left(\mathrm{Mt}^{-} \mathrm{ha}^{-1}\right)\end{array}$ & $L: D$ & Fruits/plant & $\begin{array}{c}\text { Yield } \\
\left(\mathrm{Mt}^{\mathrm{t}} \cdot \mathrm{ha}^{-1}\right)\end{array}$ & $\mathrm{L}: \mathrm{D}$ & Fruits/plant & $\begin{array}{c}\text { Yield } \\
\left(\mathrm{Mt}^{-} \mathrm{ha}^{-1}\right)\end{array}$ & $L: D$ \\
\hline $\begin{array}{l}\text { Raleigh } \\
\text { Calypso }\end{array}$ & $\begin{array}{l}6.8 \\
5.6\end{array}$ & $\begin{array}{l}40.9 \\
43.0\end{array}$ & 2.7 & 6.0 & 43.2 & 2.5 & 4.3 & 26.0 & 3.2 \\
\hline Regal & 8.1 & 43.0 & $\begin{array}{l}2.9 \\
2.9\end{array}$ & $\begin{array}{l}5.1 \\
6 .\end{array}$ & & 2.7 & 4.1 & 22.7 & \\
\hline Calico & 5.1 & 40.8 & 2.9 & $\begin{array}{l}0.4 \\
5.8\end{array}$ & $\begin{array}{l}44.3 \\
37.6\end{array}$ & $\begin{array}{l}2.6 \\
2.6\end{array}$ & 4.1. & 27.3 & 3.3 \\
\hline LSD (5\%) & 1.9 & 6.6 & $\ldots$ & $\cdots$ & -.- & $\begin{array}{l}2.0 \\
\ldots . .\end{array}$ & $\begin{array}{l}3.8 \\
0.7\end{array}$ & $\begin{array}{r}19.3 \\
4.9\end{array}$ & $\begin{array}{l}3.0 \\
\ldots\end{array}$ \\
\hline
\end{tabular}

2Data are for three harvests in 1983 and 1984 and two harvests in 1986. L : D is the length : diameter ratio of 35-mm-diameter fruits (fresh in 1983, 1984 and brinestock in 1986; 10-fruit samples). 


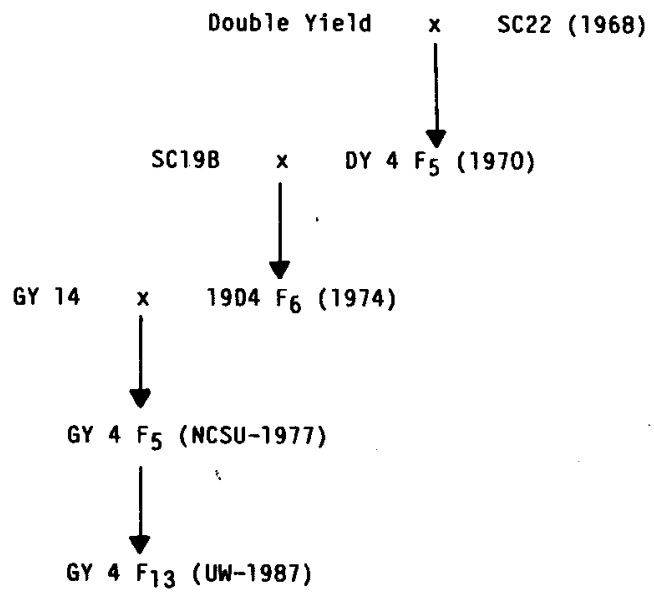

Fig. 1. History of breeding and development of Gy 4.

Table 3. Diseases for which Gy 4 has been evaluated in field and greenhouse tests.

\begin{tabular}{|c|c|c|c|}
\hline Pathogen & Common name & Test $^{2}$ & Reaction ${ }^{y}$ \\
\hline Cladosporium cucumerinum Ell. \& Arth. & Scab (spot rot) & $\mathrm{GH}+\mathrm{F}$ & $\mathbf{R}$ \\
\hline Cucumber mosaic virus & $\mathrm{CMV}$ & $\mathrm{GH}+\mathrm{F}$ & M \\
\hline Pseudomonas syringae pv. lachrymans (Smith \& & & GH & $\mathbf{R}$ \\
\hline Bryan) Young et al. & Angular leafspot & & \\
\hline $\begin{array}{l}\text { Colletotrichum orbiculare (Berk. \& Mont.) } \\
\text { von Arx }\end{array}$ & Anthracnose & $\mathrm{GH}+\mathrm{F}$ & $\mathbf{R}$ \\
\hline Pseudoperonospora cubensis (Berk. \& Curt.) & & $\mathrm{GH}+\mathrm{F}$ & $\mathbf{R}$ \\
\hline Rostow & Downy mildew & & \\
\hline $\begin{array}{l}\text { Sphaerotheca fuliginea (Schlecht.: Fr.) Poll. } \\
\text { Fusarium oxysporum (Schlecht.) }\end{array}$ & Powdery mildew & GH & $\mathbf{R}$ \\
\hline Snyd. \& Hans f. sp. cucumerinum Owen & Fusarium wilt & & $\mathbf{R}$ \\
\hline Didymella bryoniae (Auersw.) Rehm & Gummy stem blight & $\mathrm{F}$ & I \\
\hline Rhizoctonia solani Kuhn & Belly rot & $\mathrm{F}$ & I \\
\hline
\end{tabular}

${ }^{x}$ Tests were on mature plants in the field (F), or on seedlings in the greenhouse (GH). yHost reaction was resistant (R), moderately resistant (M), or intermediate (I).

\section{Description}

Vines. Gy 4 has moderate size, mediumgreen vines with an indeterminate, branched plant type or habit. Leaves are medium size. Vine growth is less than Gy 14 under hot, humid conditions common to the spring and summer production seasons of the southeastern United States and in the more temperate midwest production areas.

Flowering habit. The plants are gynoecious, nonparthenocarpic, and reach $50 \%$ flowering when plants are $\approx 30$ days old (when grown under controlled 30/20C day/night conditions). Flowering is sequential and usually begins at the first node.

Fruits. Gy 4 is a pickling cucumber with short, dark-green fruits and white spines (Fig. 2). The fruits are coarse-spined (moderately warted), and have a slight speckling and striping (not uniform green), as is typical of American pickling cucumbers. Gy 4 has a L: D ratio of $\approx 2.8$ for 35 -mm-diameter fruits.

Resistance. Gy 4 has field resistance to seven diseases 'common in the United States (Table 3): 'scab, cucumber mosaic. virus, downy mildew, powdery mildew, anthracnose, angular leaf spot, and fusarium wilt. It has moderate tolerance to gummy stem blight and Rhizoctonia fruit rot. Gy 4 is susceptible to or untested for reaction to target leaf spot, bacterial wilt, zucchini yellows mosaic virus, and watermelon mosaic virus.

Seeds. Mature seeds of Gy 4 are smaller

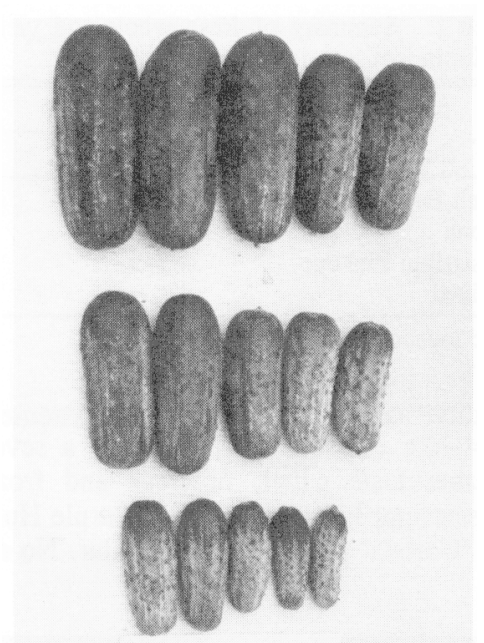

Fig. 2. Typical fruits of Gy 4 pickling cucumber inbred.

than those of Gy 14 (produced in North Carolina or Wisconsin), although germination is similar in the two lines.

\section{Availability}

Small amounts of breeder seed may be obtained from R.L.L. 